(C) 2013

Сенчук Т. Ю., аспірант *

Полтавська державна аграрна академія

\title{
ПІДГОТОВЧА РОБОТА ДЛЯ ПРОВЕДЕННЯ ПОРІВНЯННЯ НАСЛІДКІВ ЗИМІВЛІ НА РІЗНИХ ВИДАХ КОРМУ ТА ЇЇ ВПЛИВ НА РОЗВИТОК БДЖОЛИНИХ СІМЕЙ
}

\section{Рецензент - кандидат сільськогосподарських наук Т. М. Рак}

\begin{abstract}
У даний час переважна кількість сільськогосподарських угідь, на яких бджоли можуть збирати собі зимовий корм, зайнята соняшником. Мед із соняшника характеризується високою здатністю до кристалізації, що значно погіршує зимівлю бджіл і може призвести до загибелі бджолиної сім'ї. Наші дослідження спрямовані на визначення впливу медів із низькою здатністю до кристалізаичї та соняшникового меду на хід зимівлі та розвиток бджсолиних сімей у ранньовесняний період. Ми провели необхідну підготовчу роботу для організації зимівлі на різних видах меду: визначення медового запасу місиевості, склали медовий баланс місиевості та календар цувітіння медоносів, забезпечили різними кормовими запасами бджолині

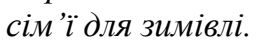

Ключові слова: бджолині сім'ї, вуглеводний корм, мед, зимівля.

Постановка проблеми. Для бджільництва вкрай важливим $\epsilon$ те, що мед виступає не лише товарною продукцією, а й основним вуглеводним кормом для бджіл протягом року. У житті бджолиної сім'ї існує два чітко виражених періоди: період активної життєдіяльності й період зимового спокою. Під час періоду активної життєдіяльності бджолина сім'я проявляє себе як господарська одиниця, тобто нарощує силу сім'ї, запилює рослини, заготовляє корми, будує гніздо тощо. В період зимового спокою бджолина сім'я намагається зберегти себе як біологічну одиницю. Впродовж цього періоду суттєвий вплив на результат зимівлі має якість і кількість кормів, тобто меду.

Аналіз останніх досліджень i публікацій, у яких започатковано розв'язання проблеми. Свого часу академік А. М. Бутлєров говорив: «Зимівля бджіл - найскладніша задача бджільництва. Зима приносить пасічнику головні збитки, часто непередбачувані, а тому й невідворотні. Тому все, що стосується зимівлі та ії результатів, повинно в вищій мірі цікавити пасічни- ків». Гарна зимівля визначається не тільки тим, щоб усі сім’і залишилися живими, як зазвичай вважають, але й їх якістю - збереженням властивої їм енергії, активності, працездатності, щоб гнізда залишилися чистими та не було проявів нозематозу [3].

Медоносні бджоли володіють вражаючою пристосованістю до низьких температур і тривалої зими. Вони навчилися не лише створювати для свого життя тепло, а й вільно зберігати його. Таким чином, загибель бджолиних сімей від морозів неможлива. Причина поганої зимівлі бджіл на пасіках - не в низьких температурах повітря та їх коливаннях, а в найгрубіших порушеннях умов, до яких бджоли пристосувалися в своїй еволюційній історії. Одна з вирішальних причин вдалої зимівлі - якість і кількість кормових запасів. Три четверті сімей помирають тільки від голоду [5].

Корм дорослих бджіл складається 3 меду та пилку: мед забезпечує їх вуглеводами головним чином у формі глюкози та фруктози, а пилок білками. Найголовніша властивість меду, що впливає на хід і якість зимівлі, - здатність кристалізуватися. Мед, вироблений з нектару більшості квіткових рослин, довго не кристалізується, в той час як соняшниковий мед кристалізується досить швидко. Наявність значної кількості закристалізованого меду в щільниках вкрай негативно впливає на хід зимівлі, поскільки взимку бджоли харчуються тільки рідким кормом. Ще десять років тому зимовий корм містив у собі не тільки соняшниковий мед, а й мед 3 інших рослин. Це сприяло тому, що мед починав кристалізуватися значно пізніше, й кристалізація меду вже не була такою небезпечною. Однак за останні роки кормова база бджільництва радикально змінилася за рахунок того, що сільськогосподарські підприємства надають перевагу посівам соняшнику. Мед із цієї рослини у вигляді зимового корму не рекомендують залишати

* Науковий керівник - доктор сільськогосподарських наук А. А. Поліщук 


\section{СТОРІНКА МОЛОДОГО ВЧЕНОГО}

бджолиним сім'ям. Доводиться соняшниковий мед заміняти на цукровий сироп [2]. Однак дослідженнями виявлено, що осінні підгодівлі бджіл цукром надзвичайно шкідливі, - вони сильно зношують бджіл і підвищують небезпеку їх загибелі, а також негативно впливають на весняний розвиток бджолиних сімей та їхню опірність хворобам. Доведено, що в квітковому медові вміст мінеральних речовин становить $0,1-0,3 \%$, а в цукрі цих речовин взагалі немає [1].

Мета і завдання досліджень. Мета: вивчення впливу меду різних видів рослин на хід зимівлі та подальший розвиток бджолиних сімей української степової породи бджіл.

Відповідно до мети, перед нами постали завдання: провести визначення медового запасу місцевості; скласти нектароносний баланс місцевості та календар цвітіння медоносів; провести підготовку сімей до зимівлі на різних сортах меду.

Матеріал і методи досліджень. Дослідження проводимо в природно-кліматичних умовах лісостепової зони України, в Полтавській області, на базі пасіки Полтавської обласної громадської організації «Спілка пасічників». Для цього ми відібрали 2 групи по 5 сімей, однакової сили в кожній. Піддослідні сім'ї утримуються у вуликах-лежаках із рамками розміром 435х300 мм; зимівля проводиться на вулиці; зимове гніздо сформоване зі світло-коричневих рамок, кожна 3 яких має не менше 2 кг запечатаного меду; рамки розміщені на холодний занос, вентиляція проводиться через нижні льотки.

Результати досліджень. Перша група зимує на соняшниковому медові, а друга - на медові 3 різнотрав'я. Для забезпечення чистоти досліду для другої групи кормові рамки заготовлялися до початку цвітіння соняшнику. Якість зимівлі піддослідних сімей індивідуально та групами в цілому оцінюватиметься кількістю спожитого меду за час зимівлі, силою бджолиних сімей та кількістю підмору після зимівлі, кількістю розплоду на період першого обльоту й через місяць після нього, наявністю опоношення.

За весняно-літній період 2012 року нами було проведено визначення медового запасу місцевості (див. рис.).

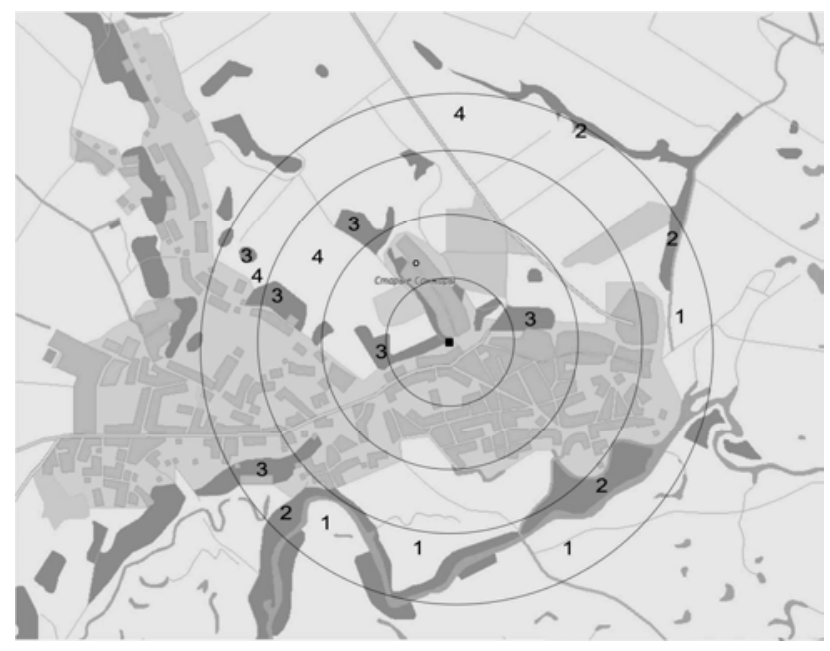

\section{Рис. План медоносних угідь дослідної пасіки}

Оцінка медоносних запасів була проведена в радіусі 2 км навколо пасіки - це оптимальний радіус продуктивного льоту бджіл. По карті визначили площі окремих угідь, а потім склад i площі окремих медоносних рослин. На карті відмічені угіддя, що становлять кормову базу нашої пасіки: 1 - луки; 2 - лісові насадження; 3 акація біла; 4 - соняшник.

На основі отриманих даних було складено медовий баланс місцевості (табл. 1).

У таблиці 1 вказуються площі по окремих угіддях, види медоносів та їх нектаропродуктивність. Для визначення медпродуктивності окремих угідь перемножуємо гектарну норму запасу цукру на кількість гектарів угідь. Встановлена медпродуктивність по кожному з угідь додається

\section{1. Медовий баланс місцевості}

\begin{tabular}{|c|c|c|c|c|c|c|c|}
\hline \multirow{3}{*}{$\begin{array}{c}\text { Медоносні } \\
\text { культури та угіддя }\end{array}$} & \multirow{3}{*}{$\begin{array}{l}\text { Площа, } \\
\text { га }\end{array}$} & \multirow{3}{*}{$\begin{array}{c}\text { Тривалість } \\
\text { цвітіння, } \\
\text { дні }\end{array}$} & \multirow{3}{*}{$\begin{array}{c}\text { Медо- } \\
\text { продуктив- } \\
\text { ність, кг/га }\end{array}$} & \multicolumn{4}{|c|}{ Запас меду } \\
\hline & & & & \multicolumn{2}{|c|}{ усього } & \multicolumn{2}{|c|}{$\begin{array}{c}\text { використовуваний } \\
\text { бджолами (50 \%) }\end{array}$} \\
\hline & & & & Кг & $\begin{array}{c}\text { \% до зага- } \\
\text { льного }\end{array}$ & $\begin{array}{l}\text { усього за } \\
\text { період } \\
\text { цвітіння }\end{array}$ & $\begin{array}{c}\text { за } 1 \text { день } \\
\text { цвітіння, } \\
\text { кг }\end{array}$ \\
\hline Лісові насадження & 57 & 50 & 50 & 2850 & 10,7 & 1425 & 28,5 \\
\hline Садки & 9 & 11 & 25 & 225 & 0,8 & 112,5 & 10,2 \\
\hline Біла акація & 23 & 10 & 500 & 11500 & 43,2 & 5750 & 575 \\
\hline Луки & 230 & 140 & 30 & 6900 & 25,9 & 3450 & 24,6 \\
\hline Соняшник & 129 & 31 & 40 & 5160 & 19,4 & 2580 & 83,2 \\
\hline Усього & 448 & - & - & 26635 & 100 & 13317,5 & - \\
\hline
\end{tabular}


СТОРІНКА МОЛОДОГО ВЧЕНОГО

\section{2. Календар цвітіння медоносів}

\begin{tabular}{|c|c|c|c|c|c|c|c|c|}
\hline \multirow[b]{2}{*}{ Назва рослин } & \multicolumn{7}{|c|}{ Період цвітіння медоносів } & \multirow{2}{*}{$\begin{array}{c}\text { Медо- } \\
\text { про- } \\
\text { дуктив- } \\
\text { ність, } \\
\text { кг/га } \\
\end{array}$} \\
\hline & 03.12 & 04.12 & 05.12 & 06.12 & 07.12 & 08.12 & 09.12 & \\
\hline Верба козяча & & & & & & & & 80 \\
\hline $\begin{array}{c}\text { Верба } \\
\text { гостролиста }\end{array}$ & & & & & & & & 50 \\
\hline $\begin{array}{c}\text { Клен } \\
\text { гостролистий }\end{array}$ & & & & & & & & 200 \\
\hline Сади & & & & & & & & 25 \\
\hline $\begin{array}{c}\text { Клен } \\
\text { татарський }\end{array}$ & & & & & & & & 300 \\
\hline Біла акація & & & & & & & & 500 \\
\hline $\begin{array}{c}\text { Лох вузько- } \\
\text { листий }\end{array}$ & & & & & & & & 200 \\
\hline $\begin{array}{c}\text { Вероніка } \\
\text { лікарська }\end{array}$ & & & & & & & & 50 \\
\hline $\begin{array}{l}\text { Кульбаба } \\
\text { лікарська }\end{array}$ & & & & & & & & 100 \\
\hline $\begin{array}{c}\text { Волошка } \\
\text { лучна }\end{array}$ & & & & & & & & 130 \\
\hline $\begin{array}{c}\text { Цикорій } \\
\text { звичайний }\end{array}$ & & & & & & & & 100 \\
\hline $\begin{array}{c}\text { Осот } \\
\text { щетинистий }\end{array}$ & & & & & & & & 140 \\
\hline $\begin{array}{l}\text { Буркун } \\
\text { жовтий }\end{array}$ & & & & & & & & 200 \\
\hline $\begin{array}{c}\text { Шавлія } \\
\text { кільчаста }\end{array}$ & & & & & & & & 400 \\
\hline $\begin{array}{c}\text { Синяк } \\
\text { Звичайний }\end{array}$ & & & & & & & & 350 \\
\hline $\begin{array}{c}\text { Липа } \\
\text { широколиста } \\
\end{array}$ & & & & & & & & 800 \\
\hline $\begin{array}{c}\text { Липа } \\
\text { дрібнолиста }\end{array}$ & & & & & & & & 600 \\
\hline $\begin{array}{c}\text { Собача } \\
\text { кропива }\end{array}$ & & & & & & & & 300 \\
\hline $\begin{array}{c}\text { Плакун } \\
\text { верболистий }\end{array}$ & & & & & & & & 300 \\
\hline $\begin{array}{l}\text { Материнка } \\
\text { звичайна }\end{array}$ & & & & & & & & 70 \\
\hline $\begin{array}{c}\text { Осот } \\
\text { польовий }\end{array}$ & & & & & & & & 250 \\
\hline Буркун білий & & & & & & & & 300 \\
\hline Соняшник & & & & & & & & 40 \\
\hline Герань лучна & & & & & & & & 30 \\
\hline
\end{tabular}

й сума дорівнюватиме медовому запасу місцевості. Тобто, запас місцевості становить 26635 кілограмів. Водночас встановлено, що бджолині сім'ї можуть продуктивно використати близько 50 \% нектарного запасу місцевості, що становить 13317,5 кілограмів. Проте розрахунків медового 
балансу недостатньо. Тому ми склали календар цвітіння медоносів у районі розташування дослідної пасіки (табл. 2). 3 календаря цвітіння медоносів видно, що дослідна пасіка повністю забезпечена взятком на протязі всього сезону. Дана місцевість за кормовою базою підходить для проведення дослідів [3, 4].

За період медозбору була проведена заготівля кормових запасів, на яких зимують піддослідні групи. За допомогою пилкового аналізу меду та спеціальних атласів визначали у відсотковому співвідношенні вміст пилкових зерен та їх відповідність певним видам рослин. Це підтвердило те, що піддослідні групи дійсно зимуватимуть на соняшниковому медові та меду 3 різнотрав'я. В останній декаді жовтня на дно вулика під гніздом встановили білий папір для збору воскової крихти та можливих кристаликів зацукрованого меду, - це дасть нам змогу контролювати рух

\section{БІБЛІОГРАФІЯ}

1. Мартынов А. Г. Назин С. Н. Сахар и варроатоз // Пчеловодство. - 1990. - №10. - С. 13-15.

2. Поліщук В. П. Бджільництво. - Львів: «Український пасічник», 2001. - 296 с.

3. Стройков С. А. Кулинария для пчел // Пчеловодство. - 1990. - №1. - С. 36-38.

4. Хмара П. Я., Муквич Н. В. Промислова техно- зимового клубу та наявність закристалізованого меду [6].

Висновки: 1. У даний час наука і практика рекомендують помірне використання цукру в якості зимового корму для бджіл. У багатьох випадках ним краще взагалі не користуватися, доцільніше запасати повні рамки доброякісного меду в період головного медозбору й формувати ними гнізда сімей для зимівлі. Це давній класичний прийом, і про нього не слід забувати в наш час.

2. Поскільки в умовах лісостепової зони України, а саме в Полтавській області, останнім часом найпоширенішими медоносними культурами для забезпечення кормових запасів на зиму $\epsilon$ лучне різнотрав'я та соняшник, то наступним етапом досліджень буде вивчення і порівняння наслідків зимівлі на різних видах корму та іiі вплив на розвиток бджолиних сімей.

логія бджільництва. - К. : Урожай, 1987. - 96 с.

5. Чергик Н. І., Бага А. М. Кормова база бджільництва. - К. : Урожай, 1976. - 186 с.

6. Шабаршов И. Искусство пчеловода проверяется зимовкой // Пчеловодство. - 1990. - №8 C. 2-4. 